\title{
The fear factor in health fundraising
}

Previously published at www.cmaj.ca

$\mathrm{T}$ he boy in the poster gasps for air, his face barely above the surface of water. The tagline reads: "Cystic fibrosis is like drowning on the inside." Advocacy groups that raise money to combat illnesses often struggle to capture the public's attention. There are many worthy causes out there, some higher profile than others, and getting people to notice a particular cause is hard enough - getting them to care about it harder still. Using an alarming image or message in an advertising campaign can be an effective means of making people pay attention.

But startling ads to raise awareness about diseases can have quite a different effect on people suffering from those diseases. For them, such ads can be distressing, reminders of a future that is anything but certain. Some critics claim ads that depict worst-case sce- narios border on fear-mongering and, in some cases, don't even accurately portray those worst-case scenarios.

Cystic fibrosis (CF) ads are often "very vivid and shocking ads with kids in them that actually hurt families and the kids themselves," says Dr. Annie Janvier, a clinical ethicist at Sainte-Justine Hospital in Montréal, Quebec. Parents are often scared by the ads, while children with the disease may accuse their parents of lying to them about their condition, she says, adding that even doctors tend to dislike the ads, though they don't criticize the Canadian Cystic Fibrosis Foundation because the group raises money to help their patients.

The ads are also misleading, Janvier says. CF, a fatal genetic disease that affects about one in 1600 people, causes mucus to accumulate in the lungs, affecting breathing. But people receiving proper medical care would at no time, not even when dying, feel as if they were drowning or breathing through straws, she says. "Even the worst-case scenario is not like that. You don't die as if you are drowning. If you die in pain, you have bad medical care. If someone feels like they are breathing through a straw, you have bad medical care."

But according to June Pierotti, the director of communications for the Canadian Cystic Fibrosis Foundation, the ads are not intended to mislead, scare or hurt anybody. Adults with CF and parents of CF sufferers are consulted on advertising concepts. Most people don't know much about CF and hard-hitting advertisements are necessary to get people to realize it is a serious problem that deserves attention.

The ads are "aimed at people who don't know about CF, but you can't shield people who have CF from seeing the ads, she says." - Roger Collier, CMAJ

DOI:10.1503/cmaj.109-3335

\section{ECZEMA FLARES ARE ALWAYS WAITING TO ATTACK.}

